\title{
DOES OWNERSHIP STRUCTURE MATTER? A COST EFFICIENCY STUDY OF LIFE INSURANCE FIRMS IN INDONESIA
}

\author{
Riski Wicaksono* and Tri Mulyaningsih** \\ *,*** Department of Economics, Universitas Sebelas Maret, Surakarta, Indonesia. \\ ** Email: trimulyaningsih@staff.uns.ac.id
}

\begin{abstract}
This paper is about the cost and profit efficiency of Indonesia's life insurance industry. Using data from 2010-2014, we compare cost and profit efficiency among local and joint venture insurers. Our empirical analysis, based on a time-invariant translog cost model, reveals mean cost allocation and profit efficiency scores of 0.36 and 0.52 , respectively. Interestingly, we find that domestic insurers are more cost efficient compared to joint venture insurers; however, joint venture insurers maximize profit more.
\end{abstract}

Keywords: Life insurance industry; Insurers; Cost efficiency; Profit efficiency; Translog model. JEL Classification: L1; L25; G22.

\author{
Article history: \\ Received : : September 19, 2018 \\ Revised : June 19, 2019 \\ Accepted : June 21, 2019 \\ Available online : October 15, 2019 \\ https://doi.org/10.21098/bemp.v22i3.957
}




\section{INTRODUCTION}

Life insurance plays an important role in the insurance industry market in Indonesia. Based on data from the Financial Services Authority of Indonesia (Otoritas Jasa Keuangan, or OJK), in 2019, the life insurance industry generated an investment value of Rp 478.16 trillion (US\$34 billion), or $43 \%$ of the total investment in the overall insurance industry. In addition, life insurance helps reduce the impact of financial losses for individuals and businesses through risk-pooling.

Nevertheless, despite its significant role in the financial sector and the economy, studies revealed that the insurance industry in developing countries, including Indonesia, is characterized by low efficiency (e.g., Diacon et al., 2002; Eling and Luhnen, 2010; Abidin and Cabanda, 2012; Viverita, Wulandari, and Cabanda, 2016). Insurance companies in developing countries are technically and allocatively inefficient ${ }^{1}$ (Eling and Luhnen, 2010). Eling and Luhnen (2010) reported that Indonesia's efficiency score is only 0.22 , based on data envelopment analysis and 0.59 , based on stochastic frontier analysis (SFA). Indonesia-specific studies support these findings. Viverita et al. (2016), for instance, found cost efficiency scores of $0.443,0.442$, and 0.390 in 2006, 2007, and 2008, respectively. Abidin and Cabanda (2012), who focused on non-life insurance firms in Indonesia between 2005 and 2007, found cost efficiency scores of 0.587, 0.599, and 0.579 for 2005, 2006 and 2007, respectively. While the efficiency scores are higher in these studies, they do not imply efficiency compared to the high efficiency scores found for developed countries (see also Diacon et al., 2002).

In this paper, we focus on Indonesia's insurance industry. Our study is motivated by several reasons. First, the market's life insurance segment constitutes almost half of Indonesia's insurance market. Specially, according to the OJK (2019), the life insurance industry contributes $42 \%$ of the total assets of the insurance industry and $43 \%$ of its total investments as of July 2019. It is therefore imperative to understand the efficiency of the industry. Second, the ownership structure is unique. Almost half of all insurers are joint ventures. A significant increase in the establishment of joint ventures was observed in 2015, when three joint ventures entered the market. Further, the joint venture insurers contributed $75 \%$ of the total assets of all life insurers in Indonesia in 2017.

Third, this ownership structure in the life insurance industry has contributed to different levels of performance efficiency. For instance, Simu and Yulistyanto (2013) found significant differences in performance between domestic and joint life insurance companies, as measured by financial statement variables. For example, based on profitability ratios, joint venture life insurance companies were discovered to be more efficient than domestic life insurance companies. Furthermore, based on the solvency ratio of the capital and the leverage ratio, domestic insurers were superior to the joint venture companies. However, joint venture life insurance companies dominated in terms of their liquidity ratio and risk-based capital.

\footnotetext{
1 Insurers are technically efficient if they have the capability to produce a particular level of output at minimum cost. Further, insurers are allocatively efficient if they can allocate their resources efficiently.
} 
The industry offers both life and non-life insurance services with almost equal contribution shares. Despite its large potential market, the insurance industry is prohibited from penetrating foreign insurance companies, except if these collaborate with local insurers and establish a joint venture. This implies Indonesia's localization of ownership in the insurance market, where serving insurers in Indonesia must be owned by an Indonesian national.

We not only analyze Indonesian insurance companies as a whole but, in additional analysis, we split them into two groups: domestic owned and joint ventures. This is an important step, because we believe that the localization of ownership in the Indonesian insurance industry could reduce the competitive market's positive effect on efficiency in the local industry. The argument in the literature is that an increase in the number of insurers through the penetration of foreign institutions reduces market concentration, which subsequently enhances competition in the local market. Mulyaningsih et al. (2015), for instance, showed that the mode of entry of foreign banks into the local market determines its impact on competition. Based on these arguments, we hypothesize that the efficiency and profitability scores between domestic and joint venture insurers should be different. Subsequently, the novelty of our work lies precisely in the proposal and testing of this hypothesis.

Using data from Indonesia's life insurance industry, we show that the overall efficiency score for all 35 companies is 0.36 . These companies have a higher profitability score, of 0.52 . When we split these companies into domestic companies (19 insurers) and joint ventures (16 insurers), we find that domestic companies are at least twice as cost efficient compared to joint venture companies, with a score of 0.48 versus 0.21 . By comparison, joint venture companies are more profitable, with a profitability score of 0.56 , compared to domestic companies, with a score of 0.49 .

Our contributions to the literature are twofold. First, we conduct a timevarying analysis of the cost and profitability scores. Previous studies in Indonesia, such as those of Abidin and Cabanda (2012) and Viverita et al. (2016), focused on cross-sectional data to measure the efficiency score. Therefore, in those studies, the variation of efficiency was captured across insurers and not over time. The studies found cost efficiency to be 0.390 in 2008 Viverita et al. (2016) and 0.579 in 2007 (Abidin and Cabanda, 2012). We complement these studies by finding a cost efficiency score of 0.36 .

Our second contribution is to address insurer heterogeneity. In the Indonesian market, there two types of insurers: domestic owned and joint ventures. They operate with a different cost and revenue structure, which has implications for efficiency. We add to these studies in Indonesia and other countries by showing significant differences in cost efficiencies when we account for the heterogeneity of insurers. A key outcome of our analysis is the finding that domestic insurers are twice as cost efficient as joint venture insurers.

The remainder of this paper is organized as follows. Section II discusses the methodology and data. Section III discusses the analysis and discussion, and Section IV presents the conclusion and recommendation. 


\section{METHODOLOGY AND DATA}

A. Frontier Analysis of Efficiency in Insurance Industry

This study employs the SFA approach. Specifically, our measurement of the efficiency of the insurance industry in Indonesia utilizes an input-oriented approach, because it concerns cost minimization and profit maximization (Coelli et al., 2005). According to the input-oriented approach, the source of a firm's efficiency depends on its capability to minimize costs or to maximize revenues/ profits. Most studies discuss the efficiency of financial institutions concerned with their capability to minimize costs. Therefore, the measurement of firm efficiency is determined by the capacity to produce a given amount of output at minimum cost, using the best mix of inputs, given the prevailing input prices. This assumption is relevant to the objective of this study, that is, in the Indonesian market, insurers generate both insurance claims and investments by utilizing a set of inputs.

According to Kumbhakar and Lovell (2000), the basic model of a cost frontier using panel data is $E_{i t} \geq C\left(Y_{i t}, w_{i t}, \beta\right)$, where the operational cost $\left(E_{i t}\right)$ of insurer $i$ at time $t$ is a function of the output level $\left(Y_{i t}\right)$, input prices $\left(W_{i t}\right)$, and the cost frontier $C\left(Y_{i t}, w_{i t}, \beta\right)$. Further, cost efficiency $(C E)$ equals the ratio of the minimum cost to the actual cost,

$$
C E_{i t}=\frac{C\left(Y_{i t}, w_{i t}, \beta\right)}{E_{i t}}
$$

where the efficiency score ranges between zero and one, with a lower value signaling less efficient insurers:

Equation (1) assumes that the cost frontier of $C\left(Y_{i t}, w_{i t}, \beta\right)$ is deterministic. It disregards the fact that cost is also determined by a random shock beyond the control of firms. Thus, the proper equation to measure efficiency based on the parametric approach of SFA consists of a deterministic $C\left(Y_{i t}, w_{i t}, \beta\right)$ and a random shock $\exp \left\{V_{i t}\right\}$, as follows:

$$
C E_{i t}=\frac{C\left(Y_{i t}, w_{i t}, \beta\right) \cdot \exp \left\{v_{i t}\right\}}{C\left(Y_{i t}, w_{i t}, \beta\right)}
$$

Generally, studies discussing firm efficiency focus on either technical efficiency or allocative efficiency. Technical efficiency refers to a firm's ability to locate its production function at the production frontier (isoquant). This implies that firms are capable of producing a certain output with the lowest input. The production functions of less efficient firms are technically below the production frontier (Kumbhakar et al., 2015). Moreover, studies on firm efficiency are concerned about firms' capability to select a set of inputs that generate the lowest costs. Rai (1996), Cummins and Weiss (1998), Coelli et al. (2005), and Eling and Luhnen (2010) show how firms select the best combination of inputs at the same output frontier level. This leads to a measurement of allocative efficiency that reveals the lowest-cost combination to produce a certain level of output.

According to Kumbhakar et al. (2015), firms are allocatively efficient if their production is at the level where the ratio of input prices equals the slope of the isoquant (the marginal rate of technical substitution), as follows: 


$$
\frac{d x_{2}}{d x_{1}}=-\frac{f_{1}}{f_{2}}=\frac{w_{1}}{w_{2}}
$$

where the marginal rates of technical substitution of inputs $1\left(x_{1}\right)$ and $2\left(x_{2}\right)$, written as $\left(\frac{d x_{2}}{d x_{1}}\right)\left(x_{i}\right)$, equals the ratio of input price $1\left(w_{1}\right)$ to input price $2\left(w_{2}\right)$, written as.

Meanwhile, considering their to maximize profits, firms are required to both minimize costs and maximize revenues (Maudos et al., 1999). Therefore, the measurement of efficiency by focusing only on cost minimization is not sufficient. Moreover, some studies, such as Berger and Mester (1997), Lozano (1997), and Rogres (1998), concluded that profit inefficiency is always greater than cost efficiency. Maudos et al. (1999) argued that profit inefficiency was due to the selection of an incorrect output composition or the creation of an invalid pricing policy.

According to Berger and Mester (1997), there are two approaches to measuring profit efficiency, using either standard profit efficiency or alternative profit efficiency. Using the standard approach, we measure profit efficiency by comparing the firm's ability to generate maximum profits for particular outputs and inputs to a benchmark firm with industry best practices. This approach assumes that the markets for both input and output are perfectly competitive (Maudos et al., 1999), with profit function

$$
\Pi=\Pi(w, p, v, u)
$$

or, in logarithmic terms,

$$
\ln (\Pi+\theta)=\mathrm{f}(w, p)+\ln v-\ln u
$$

to produce positive logarithmic values of profits, we must add a constant value of $\theta$ to this equation. In addition, $p$ is the price of output and $\pi$ refers to the profit level, which is determined by the profit frontier of the output vector of input and output prices. Since the function is stochastic, profits are also determined by a random shock $(v)$ and the level of profit inefficiency $(u)$.

The assumption of perfectly competitive markets of input and output is not relevant in the case of Indonesian insurance firms. This is because Rokhim (2017) found that a few large insurers dominate the market, while a large number of much smaller insurers compete for the remaining market share. This finding is consistent with the data, which suggest that around $50 \%$ of the recorded output for claims and investments belongs to the four largest companies in the life insurance industry.

This study therefore relies on the alternative profit efficiency approach, because it assumes that the input and output markets are not competitive. According to Berger and Mester (1997), the profit efficiency model is suitable for measuring efficiency in a non-perfectly competitive market where insurers have the power to determine prices, implying some degree of market power. The data show that close to $50 \%$ of the recorded output from claims and investments belongs to the four largest companies in the Indonesian life insurance industry. 
In addition, the alternative approach incorporates variation in service quality across insurers and the unavailability of information on output prices. The alternative model employs an output vector as the determinant of profit, instead of output price information. Thus, according to the alternative profit function, insurers treat the quantity of output $(y)$ and the price of inputs $(w)$ as a given. Therefore, insurers maximize profits by adjusting the price of the output $(p)$ and the quantity of inputs (Maudos et al., 1999). The profit function is expressed as

$$
\pi_{a}=\pi_{a}(y, w, v, u)
$$

Finally, profit efficiency is calculated as the ratio between an insurer's actual profit and the maximum profit that can be generated by the most efficient insurer. Higher profit efficiency indicates greater efficiency and the most efficient insurer has a profit efficiency score of one (Maudos et al., 1999):

$$
E \pi=\frac{\pi}{\pi^{\max }}=\frac{[\exp (\pi(w, p)) \exp (v) \exp (-\ln u)]-\theta}{[\exp (\pi(w, p)) \exp (\ln v)]-\theta}
$$

The cost and profit efficiency measurement captures both technical and allocative efficiency, using a primal system approach (Kumbhakar et al. 2015). The primal approach utilizes the production function in the beginning and then uses the system that consists of the production function and the first-order conditions of cost minimization. The Cobb-Douglas or transcendental logarithm (translog) production function is then utilized and further combined with the cost minimization function. For a detailed discussion of the primal system of cost minimization and profit maximization, see Kumbhakar et al. (2015).

\section{B. Cost and Profit Efficiency Measurements of the Parametric Approach: SFA}

As discussed in the previous sections, measurement of the efficiency of both cost and profit requires the introduction of a stochastic approach, which will enable the functional model to capture random shocks and inefficiency under its error term. We use the parametric approach of SFA developed by Aigner et al. (1977). The SFA treats random shock as (i) a symmetric component of the random effect of the frontier between observations that captures the effect of uncontrollable exogenous variables and as (ii) a one-sided component of deviation capturing inefficiency (Coelli et al. 2003). SFA is also preferable because the estimated distance function accommodates multiple outputs.

The translog model is employed to estimate the cost and profit efficiency scores (Kumbhakar and Lovell, 2000). The translog of the profit function is similar to that of the cost function, with one adjustment required, and employs profits as the dependent variable: 


$$
\begin{aligned}
& \ln \left(\frac{\mathrm{TC}_{\mathrm{it}}}{\mathrm{w}_{1 \mathrm{it}}}\right)=\alpha_{0}+\alpha_{1} \ln \mathrm{Y}_{1 \mathrm{it}}+\alpha_{2} \ln \mathrm{Y}_{2 \mathrm{it}}+\beta_{2} \ln \left(\frac{\mathrm{w}_{2 \mathrm{it}}}{\mathrm{w}_{1 \mathrm{it}}}\right)+\beta_{3} \ln \left(\frac{\mathrm{w}_{3 \mathrm{it}}}{\mathrm{w}_{1 \mathrm{it}}}\right)+0.5 \alpha_{11}\left(\mathrm{Y}_{1 \mathrm{it}}\right)\left(\mathrm{Y}_{1 \mathrm{it}}\right)+ \\
& 0.5 \alpha_{22}\left(\ln Y_{2 \mathrm{it}}\right)\left(\ln Y_{2 \mathrm{it}}\right)+\alpha_{12}\left(\mathrm{Y}_{1 \mathrm{it}}\right)\left(\ln \mathrm{Y}_{2 \mathrm{it}}\right)+0.5 \beta_{22} \ln \left(\frac{\mathrm{w}_{2 \mathrm{it}}}{\mathrm{w}_{1 \mathrm{it}}}\right) \ln \left(\frac{\mathrm{w}_{2 \mathrm{it}}}{\mathrm{w}_{1 \mathrm{it}}}\right)+ \\
& 0.5 \beta_{33} \ln \left(\frac{w_{3 i t}}{w_{1 i t}}\right) \ln \left(\frac{w_{3 i t}}{w_{1 i t}}\right)+\beta_{23} \ln \left(\frac{w_{2 i t}}{w_{1 i t}}\right) \ln \left(\frac{w_{3 i t}}{w_{1 i t}}\right)+\phi_{21} \ln \left(\frac{w_{2 i t}}{w_{1 i t}}\right) Y_{1 i t}+\phi_{31} \ln \left(\frac{w_{3 i t}}{w_{1 i t}}\right) Y_{1 i t}+ \\
& \phi_{22} \ln \left(\frac{w_{2 i t}}{w_{1 i t}}\right) \ln Y_{2 i t}+\phi_{32} \ln \left(\frac{w_{3 i t}}{w_{1 i t}}\right) \ln Y_{2 i t}+v_{\text {it }}-\mu_{\text {i }} \\
& \ln \left(\frac{\mathrm{PR}_{\mathrm{it}}}{\mathrm{w}_{1 \mathrm{it}}}\right)=\alpha_{0}+\alpha_{1} \ln \mathrm{Y}_{1 \mathrm{it}}+\alpha_{2} \ln \mathrm{Y}_{2 \mathrm{it}}+\beta_{2} \ln \left(\frac{\mathrm{w}_{2 \mathrm{it}}}{\mathrm{w}_{1 \mathrm{it}}}\right)+\beta_{3} \ln \left(\frac{\mathrm{w}_{3 i \mathrm{t}}}{\mathrm{w}_{1 \mathrm{it}}}\right)+0.5 \alpha_{11}\left(\mathrm{Y}_{1 \mathrm{it}}\right)\left(\mathrm{Y}_{1 \mathrm{it}}\right)+ \\
& 0.5 \alpha_{22}\left(\ln Y_{2 \mathrm{it}}\right)\left(\ln \mathrm{Y}_{2 \mathrm{it}}\right)+\alpha_{12}\left(\mathrm{Y}_{1 \mathrm{it}}\right)\left(\ln \mathrm{Y}_{2 \mathrm{it}}\right)+ \\
& 0.5 \beta_{22} \ln \left(\frac{w_{2 i t}}{w_{1 i t}}\right) \ln \left(\frac{w_{2 i t}}{w_{1 i t}}\right) 0.5 \beta_{33} \ln \left(\frac{w_{3 i t}}{w_{1 i t}}\right) \ln \left(\frac{w_{3 i t}}{w_{1 i t}}\right)+\beta_{23} \ln \left(\frac{w_{2 i t}}{w_{1 i t}}\right) \ln \left(\frac{w_{3 i t}}{w_{1 i t}}\right)+ \\
& \phi_{21} \ln \left(\frac{w_{2 i t}}{w_{1 i t}}\right) Y_{1 i t}+\phi_{31} \ln \left(\frac{w_{3 i t}}{w_{1 i t}}\right) Y_{1 i t} \phi_{22} \ln \left(\frac{w_{2 i t}}{w_{1 i t}}\right) \ln Y_{2 i t} \phi_{32} \ln \left(\frac{w_{3 i t}}{w_{1 i t}}\right) \ln Y_{2 i t}+v_{i t}-\mu_{i}
\end{aligned}
$$

where, for insurer $i$ at time $t, \ln \left(T C_{i t}\right)$ is the natural logarithm of total operating costs In $\left(Y_{i t}\right)$, is the natural logarithm of the total score for claims and claim reserves, In $\left(P R_{i t}\right)$ is the natural logarithm of earnings profit after tax, In $\left(Y_{2 i t}\right)$ is the natural logarithm of total investments, In $\left(w_{1 i t}\right)$ is the natural logarithm of the price of labor input and business services, $\left(w_{2 i t}\right)$ is the price of debt capital, and $\left(w_{3 i t}\right)$ is the price of equity capital. Lastly, $\mu_{i t}$ is a controllable error factor (inefficiency), and $v_{i t}$ is a random uncontrollable error factor.

To ensure first-order linear homogeneity in input prices, this study randomly chooses one input price (in this case, $w_{1}$ ), and the cost (or profit) is then divided by $w_{1}$ Further, all other input prices are also divided by this input price $\left(w_{1}\right)$ to ensure linear homogeneity (Kumbhakar et al. 2015). The econometric model assumes that $v_{\text {it }}$ is normally distributed with a mean of zero and variance $\sigma^{2} N\left(0, \sigma^{2}, \sigma v^{2}\right.$. Additionally, the distribution of $\mu_{i t}$ is half-normal, with a mean of zero and variance Prediction of the cost or profit efficiency score employs the value of $\mu_{i t}$ obtained from equation (7). The following function predicts the cost efficiency score based on Battese and Coelli's (1988) model:

$$
E\left[\exp \left(-U_{i t}\right) \mid \varepsilon_{i t}\right]=\exp \left(-U_{* i t}+\frac{1}{2} \sigma_{*}^{2}\right) \frac{\left(\frac{U_{* i t}}{\sigma_{*}}-\sigma_{*}\right)}{\left(\frac{U_{* i t}}{\sigma_{*}}\right)}
$$

To determine a set of inputs and outputs for the life insurance industry, this study considers three approaches to understanding the insurance business: (a) the asset or intermediation approach, (b) the user cost approach, and (c) the value-added approach, as suggested by Berger and Humphrey (1992). The asset or intermediation approach perceives the insurance company as an intermediary that transforms financial assets from surplus units into deficits. Brocket et al. (1998) explained that, as a financial intermediary, insurers manage financial assets by borrowing funds from policyholders to further invest in the capital market and to pay claims, taxes, and other costs. The user cost approach classifies the inputs and outputs of the insurance industry based on their net contribution to company revenues (Hancock, 1985). 
Regarding the output, the financial returns on assets must be greater than the opportunity cost of funds, or it will be classified as input. Although this method is appropriate, it is very challenging to collect suitable data (Cummins and Weiss, 1998).

Cummins and Weiss (1998) argued that the production or value-added approach is the most appropriate for examining the outputs and inputs of the insurance industry. According to value-added approach, all assets and liabilities have some output characteristics. Therefore, a mutually exclusive classification for inputs and outputs is not recommended. The classification should be based on the significance of the value added based on the allocation of operating costs.

In the value-added approach, insurers have three primary service products that create value added to the output: risk pooling or risk bearing, financial services relating to insured losses, and intermediation (Eling and Luhnen, 2010). Considering the three primary roles of insurance, the first output is claims and claim reserves, representing the role of insurance as pooling risk and providing financial service related to insured losses. The second output is investment, representing the role of insurance as financial intermediation (Cummins and Weiss, 1998; Eling and Luhnen, 2010; Hu et al., 2009).

Regarding the composition of inputs, insurers employ three inputs: labor, business services, and capital (Cummins and Weiss, 1998). The measurement of efficiency requires information on labor costs and expenses related to business services and capital. The collection of labor cost information is challenging. The insurance industry employs two types of workers, insurance agents and home office workers, and they have different wage levels. Further, insurance companies do not publish data on total labor costs. To capture labor cost information, therefore, this study combines expenditures for labor and business services into operating expenses. It is argued that operating costs in the insurance industry are largely allocated to pay for wages and business services (Cummins and Weiss, 1998; Fenn et al., 2008; Eling and Luhnen, 2010). Following Eling and Luhnen (2010), this study relies on Indonesia Labour Force Survey data on average monthly wages in the service sector, collected by the Indonesian Bureau of Statistics.

The third input is capital, which consists of equity capital and debt capital (Cummins and Weiss, 1998). Equity capital is measured by the company's total equity and profits. Further, debt capital is represented by total liability (Eling and Luhnen, 2010). The price of capital is measured by the rate of a one-year Indonesian government bond, representing the price of debt capital. In addition, the price of capital is represented by the rate of return of the stock market, to capture information on the price of equity capital. Detailed information on the measures of costs, profit, input prices, and output is available in Table 1. 
Table 1.

The Operational Definition of Variable in the Empirical Model

This table explains the definition of variables to be used in the empirical model. The variables category and name appear in column 1, its symbol is represented by column 2, column 3 has its definition, and the final column notes the data source.

\begin{tabular}{|c|c|c|c|}
\hline $\begin{array}{l}\text { Variable } \\
\text { Category }\end{array}$ & Symbols & Proxy & Source \\
\hline \multicolumn{4}{|c|}{ Panel A: Dependent Variable } \\
\hline $\begin{array}{l}\text { Total } \\
\text { operational } \\
\text { cost }\end{array}$ & $\mathrm{TC}$ & $\begin{array}{l}\text { Operational costs include labour costs, } \\
\text { the cost of insurance agents, product } \\
\text { marketing costs, cost of training and } \\
\text { administrative costs }\end{array}$ & Income statement \\
\hline Total profit & $\operatorname{Pr}$ & Profit after tax & Income statement \\
\hline \multicolumn{4}{|c|}{ Panel B: Output } \\
\hline $\begin{array}{l}\text { Claim and } \\
\text { claim reserve }\end{array}$ & $Y_{1}$ & Total claim and total claim reserve & $\begin{array}{c}\text { Income statement and } \\
\text { balance sheet }\end{array}$ \\
\hline Total investment & $\mathrm{Y}_{2}$ & Total investment & Balance sheet \\
\hline \multicolumn{4}{|c|}{ Panel C: Input Price } \\
\hline $\begin{array}{l}\text { Price of labour and } \\
\text { business service }\end{array}$ & $\mathrm{w}_{1}$ & $\begin{array}{l}\text { Average monthly wages in services } \\
\text { sector }\end{array}$ & $\begin{array}{l}\text { (Indonesian Labour } \\
\text { Survey, 2015) }\end{array}$ \\
\hline $\begin{array}{l}\text { Price of debt } \\
\text { capital }\end{array}$ & $\mathrm{w}_{2}$ & $\begin{array}{l}\text { The rates of one-year treasury bill of } \\
\text { Indonesian Government Bond }\end{array}$ & $\begin{array}{l}\text { (Republik Indonesia, } \\
\text { 2016) }\end{array}$ \\
\hline $\begin{array}{l}\text { Price of equity } \\
\text { capital }\end{array}$ & $\mathrm{w}_{3}$ & $\begin{array}{l}\text { The rate of return of Indonesia stock } \\
\text { market calculated by rolling using data } \\
\text { of five years }\end{array}$ & (Yahoo Finance, n.d.) \\
\hline
\end{tabular}

\section{Testing Time-Varying and Time-Invariant Approaches}

Another basic assumption under the efficiency measurement of the SFA is that efficiency scores are time varying, that is, the scores are allowed to change over time. This study tests whether the parameter of the efficiency score is time varying or time invariant across observations between 2010 and 2014. According to Kumbhakar et al. (2015), the time-varying model permits the parameter of the efficiency score to increase or decrease during the observation period. Battese and Coelli's (1992) time-varying model is a basic model used in measuring the efficiency score. The parameter of the model equation is

$$
G(t)=\exp \{(t-T)\}
$$

where $\gamma$ is the parameter used in the estimation, and the Battese-Coelli model only uses one parameter to estimate inefficiency. Inefficiency $\left(\mu_{\mathrm{i}}\right)$ decreases if $\gamma>0$, remains constant if $\gamma=0$, and increases if $\gamma<0$ (Kumbhakar and Lovell, 2000). If the parameter $\gamma$ is positive, the company's efficiency level will tend to increase with time, and vice versa.

The log-likelihood ratio test is the best to use, whether the model is time invariant or time varying (Kumbhakar et al., 2015). 
We test the null and alternative hypotheses. The null hypothesis states that the time-invariant random effect model is better than the time-varying model of Battese and Coelli (1992). We also test the alternative hypothesis, that the timevarying decay model of Battese and Coelli (1992) is better than the time-invariant random effect model. A hypothesis test of the two alternative models reveals that the null hypothesis is accepted as the $1 \%$ confidence interval is lower than the critical value (Kodde and Palm, 1986). ${ }^{2}$ The results of the test imply that the time-invariant random effect ${ }^{3}$ model is preferred to estimate both cost and profit efficiency in the life insurance industry in Indonesia between 2010 and 2014.

\section{Data}

The data set employed to answer the proposed research question covers 35 life insurance companies, 19 of which are domestic companies and 16 joint venture companies. The financial reports of the life insurance companies were collected from the insurance statistics published by OJK (2010, 2011, 2012, 2013, 2014). This study focuses on two types of life insurance companies, according to ownership structure. The first type consists of domestic insurance companies that are fully locally owned, and the second type consists of joint venture insurance companies jointly owned by local and overseas investors. This classification of domestic versus joint ownership is used in the empirical analysis.

In addition, this study relies on secondary data on the rate of return from the stock market (which we proxy using a five-year rolling average of yearly rates of return of the Jakarta Composite Index), the Treasury bill rate (which we proxy using the one-year Indonesian government bond rate), and monthly wages corresponding to the service sector in Indonesia. These data were obtained from the Indonesian Fiscal Budget Document of 2016 and the Yahoo Finance website.

\section{ANALYSIS AND DISCUSSION}

This section analyzes the efficiency level of life insurance companies in Indonesia. We compare the cost efficiency of domestic and joint venture insurers. As discussed in the previous section, the measurement of efficiency for insurers depends on information on the firms' cost structure, profits, input prices, and output mix. General information on the cost structure, profits, input prices, and output mix is presented in Table 2. In terms of input prices, the average rates of debt capital and equity capital are $4.96 \%$ and $42.40 \%$, respectively. Further, employing data on the average wages of workers in the service industry in Indonesia, we find the price of labor to be Rp 2.41 million per month.

\footnotetext{
2 The value of the statistic of the log-likelihood ratio test of the cost frontier model is 0.76 , which is lower than the critical value of 5.41 of Kodde and Palm (1986), with an alpha of $1 \%$. The value of the statistic of the log-likelihood ratio test of the profit frontier model is 1.36, which is lower than the critical value of 5.41 of Kodde and Palm(1986), with an alpha of $1 \%$.

3 Based on the Hausman test, the random effect model is more suitable than the fixed effect model.
} 
Table 2.

Summary Statistics

This table presents descriptive statistics of selected key variables. The variables are listed in column 1 . All variables are measured in local currency (IDR) in billions except for price of debt capital and price of equity capital which are represented in percentages. The mean, standard deviation (SD), minimum, and maximum values are reported.

\begin{tabular}{|c|c|c|c|c|c|}
\hline Variable & Unit & Mean & SD & Minimum & Maximum \\
\hline \multicolumn{6}{|c|}{ Panel A: Dependent Variable } \\
\hline Total operational cost & IDR (billion) & 538 & 1,000 & 2.66 & 7,280 \\
\hline Profits & IDR(billion) & 404 & 608 & 9.52 & 3,950 \\
\hline \multicolumn{6}{|c|}{ Panel B: Output } \\
\hline $\begin{array}{l}\text { Claim and addition to } \\
\text { reserve }\end{array}$ & IDR(billion) & 2,130 & 3,080 & 1.14 & 21,600 \\
\hline Total investment & IDR(billion) & 5,310 & 9,290 & 287 & 49,500 \\
\hline \multicolumn{6}{|c|}{ Panel C: Input Price } \\
\hline $\begin{array}{l}\text { Price of labour and business } \\
\text { service }\end{array}$ & IDR(million) & 2.41 & 0.29 & 2.06 & 2.79 \\
\hline Price of debt capital & $\%$ & 4.96 & 1.13 & 3.20 & 6.50 \\
\hline Price of equity capital & $\%$ & 42.4 & 13.11 & 18.75 & 52.88 \\
\hline
\end{tabular}

Regarding the output mix, between two types of output, claims and investment, the insurance industry in Indonesia prefers its role as a financial intermediary than its role in pooling risk and providing financial services. On average, the volume of investment was more than double the value of claims and additions to reserves. Between 2010 and 2014, insurers generated Rp 5.3 trillion in investment and only Rp 2.1 trillion in claims. These data trends are also consistent with those of domestic and joint venture insurers (see Table 3 ). Table 3 shows that, on average, joint venture insurers are larger than domestic insurers.

Table 3.

Claims and Total Investments of Life Insurance Industry in Indonesia

This table reports claims and claims reserve (column 2) and total investments (column 3) for domestic and joint venture insurers. The amounts are in local IDR (billions). The data are for the period 2010 to 2014 with the last row providing yearly averages.

\begin{tabular}{lcccc}
\hline & \multicolumn{2}{c}{$\begin{array}{c}\text { Claims and Claims Reserve } \\
\text { (billion IDR) }\end{array}$} & \multicolumn{2}{c}{$\begin{array}{c}\text { Total Investments } \\
\text { (billion IDR) }\end{array}$} \\
\hline Years & Domestic & Joint-venture & Domestic & Joint-venture \\
\hline 2010 & 1,570 & 2,120 & 2,450 & 5,900 \\
2011 & 1,710 & 1,960 & 2,740 & 7,030 \\
2012 & 1,870 & 2,640 & 3,030 & 7,350 \\
2013 & 1,960 & 2,150 & 3,570 & 8,810 \\
2014 & 1,930 & 3,690 & 4,540 & 9,560 \\
\hline Average & 1,810 & 2,510 & 3,270 & 7,730 \\
\hline
\end{tabular}

In terms of cost structure, joint venture insurers experience higher operational costs compared to domestic insurers and the results are indicated in Table 4 . The operational costs of domestic insurance were Rp 242 billion, on average, between 2010 and 2014. The cost structure of joint venture insurers was almost four times 
larger than that of their domestic counterparts, at Rp 890 billion. With respect to profits, joint venture insurers record higher profits, over five times that of domestic insurers. Domestic insurers generated Rp 131 billion in profits, on average, between 2010 and 2014, whereas joint ventures recorded over Rp 600 billion in profits during the same period.

Table 4.

Operational Costs and Profits of Domestic and Joint Venture Insurances

This table reports total operational costs and profits for domestic and joint venture insurers. Figures are provided for the period 2010 to 2014 with the last row report the annual average values. All values are in local currency (IDR) billions.

\begin{tabular}{lcccc}
\hline & \multicolumn{2}{c}{$\begin{array}{c}\text { Claims and Claims Reserve } \\
\text { (billion IDR) }\end{array}$} & \multicolumn{2}{c}{$\begin{array}{c}\text { Total Investments } \\
\text { (billion IDR) }\end{array}$} \\
\hline Years & Domestic & Joint-venture & Domestic & Joint-venture \\
\hline 2010 & 191 & 626 & 64.8 & 402 \\
2011 & 216 & 727 & 80.5 & 418 \\
2012 & 250 & 897 & 92.1 & 622 \\
2013 & 263 & 1,020 & 263 & 657 \\
2014 & 288 & 1,180 & 170 & 908 \\
\hline Average & 242 & 890 & 131 & 603 \\
\hline
\end{tabular}

By utilizing inputs to produce the mix of outputs, we find that the basic data on costs, profits, and the output mix provide a general picture of insurers' production function. The outputs of joint venture insurers were twice as large as that of their domestic counterparts; however, their cost structure was four times as large. This result could indicate that joint ventures are less cost efficient than domestic insurers. It is also interesting that the profits of joint ventures are close to five times those of domestic insurers, signaling higher profit efficiency.

Domestic insurers are more cost efficient because they can locate their production function closer to frontiers. Technically, domestic firms are more efficient, since they use lower amounts of inputs. Additionally, domestic firms allocate input more efficiently, considering the input prices. However, in terms of profit efficiency, joint venture insurers are more efficient, because they are able to better select the output composition and apply more valid pricing policies compared to domestic insurers.

We next discuss the results from the translog model, which is estimated using the time-invariant random effects approach. The technique requires maximum likelihood estimation. Moreover, the SFA method is employed to estimate the cost and profit frontiers of the insurance industry in Indonesia. This study adopts two sequential steps in understanding the efficiency of the Indonesian insurance industry. First, the cost and profit frontiers were estimated using the entire population of insurers between 2010 and 2014. Second, we estimated the cost and profit frontiers across joint ventures and domestic insurers in order to compare the efficiency of the performance of the two types of insurance companies in Indonesia. 
The results are reported in Table 5. The cost frontier estimation using the translog model shows the minimum attainable cost for each level of output. The outputs of both claims and investment affect insurers' cost structure in a statistically significant manner. Regarding the profit frontier estimation, the results suggest that the price of debt capital is statistically significant in influencing the profits of the life insurance industry in Indonesia.

Table 5.

\section{Estimation of Cost Frontier using Translog Model}

This table provides estimates from the Translog model. These are estimates of cost frontier. The cost frontier estimates are in column 2 while those from the profit frontier are in column 3. Finally, $\left.{ }^{*}{ }^{* *}\right)^{* * *}$ denote statistical significance at the $1 \%(5 \%) 10 \%$

\begin{tabular}{|c|c|c|c|c|}
\hline \multirow[b]{2}{*}{ Variable } & \multicolumn{2}{|c|}{ Cost Frontier } & \multicolumn{2}{|c|}{ Profit Frontier } \\
\hline & Coefficient & $p$-value & Coefficient & $p$-value \\
\hline $\operatorname{Ln} Y_{1}$ & $10.38^{*}$ & 0.00 & 0.56 & 0.95 \\
\hline $\operatorname{Ln} Y_{2}$ & $-5.71^{*}$ & 0.00 & -1.32 & 0.88 \\
\hline $\mathrm{Lnw}_{2}^{2}$ & -9.42 & 0.31 & $77.09^{* * *}$ & 0.09 \\
\hline $\operatorname{Ln} Y_{1}^{2} Y_{1}$ & $0.15^{*}$ & 0.00 & -0.03 & 0.90 \\
\hline $\operatorname{Ln} Y_{2} Y_{2}$ & $0.22^{* *}$ & 0.01 & 0.38 & 0.20 \\
\hline $\operatorname{Ln} Y_{1}^{2} Y_{2}^{2}$ & $-0.19^{*}$ & 0.00 & -0.15 & 0.52 \\
\hline$L n w_{2} w_{2}$ & -0.27 & 0.65 & $3.85^{* * *}$ & 0.09 \\
\hline$L n w_{3} w_{3}^{2}$ & 0.24 & 0.28 & -0.73 & 0.48 \\
\hline$L n w_{2} w_{3}$ & -0.08 & 0.68 & 0.65 & 0.49 \\
\hline$L n w_{2} w_{1}$ & $0.25^{*}$ & 0.00 & -0.22 & 0.63 \\
\hline $\operatorname{Ln} w_{3} Y_{1}$ & $0.27^{*}$ & 0.00 & -0.03 & 0.91 \\
\hline$L n w_{2}^{3} Y_{2}$ & -0.13 & 0.16 & 0.24 & 0.61 \\
\hline $\operatorname{Lnw}_{3} \mathrm{Y}_{2}^{2}$ & $-0.18^{*}$ & 0.00 & 0.02 & 0.94 \\
\hline cons & $-142.15^{* * *}$ & 0.08 & $686.86^{* * *}$ & 0.10 \\
\hline Wald chi2 (13) & & \multicolumn{2}{|c|}{109.47} \\
\hline Log likelihood & \multicolumn{2}{|c|}{-93.62} & \multicolumn{2}{|c|}{-206.02} \\
\hline$R$-squared & \multicolumn{2}{|c|}{0.77} & \multicolumn{2}{|c|}{0.57} \\
\hline
\end{tabular}

Table 6 displays the efficiency scores. The mean cost efficiency score of 175 life insurance companies in Indonesia is $0.36 .{ }^{4}$ The least efficient insurer is a joint venture with an efficiency score of 0.21 . The most efficient in terms of cost allocation are domestic insurers. Overall, from this analysis, we conclude that domestic insurers are more cost efficient than joint venture insurers. In summary, on average, the efficiency score of domestic insurers is 0.27 points higher than that of joint venture insurers. This finding implies that domestic insurers are twice as efficient compared to joint venture insurers.

4 Individual company-level efficiency scores are available from the authors upon request 
Table 6.

\section{Cost and Profit Efficiency Scores in Life Insurance industry}

This table presents the cost and profit efficiency scores. These scores are reported for all insurers and for both domestic and joint venture insurers. The mean of the scores, its standard deviation (SD), the scores minimum and maximum values are also reported. The final row reports the number of observations. Finally, ${ }^{*}$ denotes that the observations for profit frontier estimation is less than cost frontier as the technique requires the positive (profit) value.

\begin{tabular}{lcccccc}
\hline \multirow{2}{*}{ Description } & \multicolumn{3}{c}{ Cost Efficiency Score } & \multicolumn{3}{c}{ Profit Efficiency Score } \\
\cline { 2 - 7 } & All & Domestic & $\begin{array}{c}\text { Joint- } \\
\text { venture }\end{array}$ & All & Domestic & $\begin{array}{c}\text { Joint- } \\
\text { venture }\end{array}$ \\
\hline Mean & 0.3563 & 0.4793 & 0.2102 & 0.5169 & 0.4877 & 0.5583 \\
SD & 0.2556 & 0.2728 & 0.1429 & 0.1812 & 0.1832 & 0.1752 \\
Minimum & 0.0329 & 0.0972 & 0.0329 & 0.1191 & 0.1191 & 0.2844 \\
Maximum & 0.9201 & 0.9201 & 0.5993 & 0.7833 & 0.7667 & 0.7833 \\
Observations & 175 & 95 & 80 & $128^{*}$ & 81 & 47 \\
\hline
\end{tabular}

We now turn to profit efficiency results, which are reported in the last column of Table 6. In the comparison between profit efficiency scores and cost efficiency scores, it is obvious that insurers are better able to maximize profits than they are able to minimize costs. The average profit efficiency score for all the insurers is about 0.52 , suggesting that insurers are capable of maximizing around $52 \%$ of their profits. The results suggest that joint venture insurers are better able to maximize profits compared to domestic insurers.

To provide some context for our results, we compare them with the findings of Eling and Luhnen (2010). We choose their study because it contains comprehensive comparative measures of the cost efficiency scores of the life insurance industry for both developed and developing countries, using the SFA. The authors concluded that the insurance industry in Denmark, Finland, France, Germany, Italy, Luxembourg, Norway, Portugal, Sweden, and Switzerland is cost efficient, with scores in excess of 0.70 . For Indonesia, they found an SFA cost efficiency score of 0.59 for non-life insurance industries.

\section{CONCLUSION AND RECOMMENDATION}

This study examines the cost and profit efficiencies of insurance companies in Indonesia. There is debate about the efficiency levels of insurers, with the literature suggesting that insurers in developed countries are relatively more cost efficient than those in developing countries. An unresolved issue in this literature is how cost and, indeed, profit efficient domestic insurers are vis-à-vis joint venture insurers. This is an issue of insurer heterogeneity. Typically, the literature, including studies on Indonesia, by considering all insurance companies in aggregate, has assumed that the cost and revenue structures of domestically owned and joint ventures are homogeneous. This is not the case. Basic data on ownership reveals that cost and revenue structures vary by ownership. Our hypothesis, therefore, is that the cost and profit efficiencies of domestic and joint venture companies will differ.

Using a data set consisting of 19 domestically owned and 16 joint venture life insurance companies in Indonesia, we show, based on the SFA method, that, while the overall cost efficiency score for all 35 firms taken together is 0.36 , domestic 
insurers are twice as cost efficient (0.48) compared to joint venture companies (0.21). On the other hand, we find that joint venture companies are more profit efficient (0.56) compared to domestic companies (0.49).

\section{REFERENCE}

Aigner, D., Lovell, C. A. K., and Schmidt, P. (1977). Formulation and Estimation of Stochastic Frontier Production Function Models. Journal of Econometrics, 6, 21-37. https://doi.org/10.1016/0304-4076(77)90052-5

Abidin, Z., and Cabanda, E. (2012). Efficiency of Non-Life Insurance in Indonesia. Journal of Economics, Business and Accountancy Ventura, 14, 197-202.

Battese, G. E., and Coelli, T. J. (1992). Frontier Production Functions, Technical Efficiency and Panel Data: With Application to Paddy Farmers in India. Journal of Productivity Analysis, 3, 153-169. https://doi.org/10.1007/BF00158774

Berger, A., and Humphrey, D. (1992). Measurement and Efficiency Issues in Commercial Banking (Vol. I). University of Chicago Press. Retrieved from http://www.nber. org/chapters/c7237

Berger, A., and Mester, L. (1997). Inside the Black Box: What Explains Differences in the Efficiencies of Financial Institutions? Journal of Banking and Finance, 21, 895-947. Retrieved from http://dx.doi.org/10.1016/S0378-4266(97)00010-1

Brockett, P. L., Cooper, W. W., Golden, L. L., Rousseau, J. J., and Wang, Y. (1998). DEA Evaluations of the Efficiency of Organizational Forms and Distribution Systems in the US Property and Liability Insurance Industry. International Journal of Systems Science, 29, 1235-1247.

Coelli, T., Estache, A., Perelman, S., and Trujillo, L. (2003). A Primer on Efficiency Measurement for Utilities and Transport Regulators (Vol. 1). The World Bank. Retrieved from http://documents.worldbank.org/curated/ en/979041468765575437/A-primer-on-efficiency-measurement-for-utilitiesand-transport-regulators

Coelli, T., Rao., D. S. P., O’Donnel, C. J., and Batesse, G. E. (2005). An Introduction to Efficiency and Productivity Analysis (2nd ed). https://doi.org/10.1007/978-1-46155493-6

Cummins, J. D., and Weiss, M. A. (1998). Analyzing Firm Performance in the Insurance Industry Using Frontier Efficiency Methods. The Wharton on Financial Institutions Center, 98-22.

Diacon, S., Starkey, K., and O'Brien, C. (2002). Size and Efficiency in European Long- term Insurance Companies: An International Comparison. The Geneva Papers on Risk and Insurance Issues and Practice, 27, 444-466.

Eling, M., and Luhnen, M. (2010). Efficiency in the International Insurance Industry: A Cross-Country Comparison. Journal of Banking and Finance, 34, 1497-1509. https://doi.org/10.1016/j.jbankfin.2009.08.026

Biener, C., and Eling, M. (2017). Organization and Efficiency in the International Insurance Industry: A Cross-Frontier Analysis. European Journal of Operational Research, 221, 454-488. https://doi.org/10.1016/j.ejor.2012.03.037

Fenn, P., Vencappa, D., Diacon, S., Klumpes, P., and O'Brien, C. (2008). Market Structure and the Efficiency of European Insurance Companies: A Stochastic 
Frontier Analysis. Journal of Banking and Finance, 32, 86-100. https://doi. org/10.1016/j.jbankfin.2007.09.005

Hallman, L. (2017). The Rolling Window Method: Precisions of Financial Forecasting. Royal Institute of Technology, School of Engineering Sciences, KTH Royal Institute of Technology.

Hancock, D. (1985). The Financial Firm: Production With Monetary and Nonmonetary Goods. Journal of Political Economy, 93, 859-880.

$\mathrm{Hu}$, X., Zhang, C., Hu, J., and Zhu, N. (2009). Analyzing Efficiency in the Chinese Life Insurance Industry. Management Research News, 32, 905-920. https://doi. org/10.1108/01409170910994123

Indonesian Labour Survey. (2015). Rata-rata Upah/Gaji Bersih Sebulan Buruh/ Karyawan/Pegawai Menurut Lapangan Pekerjaan Utama (rupiah). Retrieved from http://www.bi.go.id/sdds/SeriesGroup/05_woe_new.xls

Kodde, D.A., and Palm, F. C. (1986). Wald Criteria for Jointly Testing Equality and Inequality Restrictions. Econometrica, 54, 1243-1248. https://doi. org/10.2307/1912331

Kumbhakar, S.C., and Lovell, C. A. (2000). Stochastic Frontier Analysis. Cambridge University Press.

Kumbhakar, S. C., Wang, H.-J., and Horncastle, A. (2015). A Practitioner's Guide to Stochastic Frontier Analysis Using Stata. Cambridge University Press.

Lozano, A. (1997). Profit Efficiency for Spanish Savings Banks. European Journal of Operational Research, 98,381-394.https://doi.org/10.1016/S0377-2217(97)00354-8

Maudos, J., Pastor, J. M., and Serrano, L. (1999). Total Factor Productivity Measurement and Human Capital in OECD Countries. Economics Letters, 63, 39-44. https://doi.org/10.1016/S0165-1765(98)00252-3

Mulyaningsih, T., Daly, A., and Miranti, R. (2015). Foreign Participation and Banking Competition: Evidence From the Indonesian Banking Industry. Journal of Financial Stability, 19, 70-82. https://doi.org/10.1016/j.jfs.2015.02.001

Otoritas Jasa keuangan. (2017). Laporan Perasuransian 2017. Retrieved from http://www.ojk.go.id/id/kanal/iknb/data-dan-statistik/asuransi/Pages/ Perasuransian-Indonesia-2017.aspx

Rai, A. (1996). Cost Efficiency of International Insurance Firms. Journal of Financial Services Research, 10, 213-233. https://doi.org/10.1007/BF00114085

Republik Indonesia. (2016). Nota Keuangan Beserta Rancangan Anggaran Pendapatan dan Belanja Negara Tahun Anggaran 2016. Retrieved from https://www. kemenkeu.go.id/media/5312/nkrapbn2016.pdf

Simu, N., and Yulistyanto, A. (2013). Analisis Komparasi Kinerja Keuangan Perusahaan Asuransi Jiwa Nasional Dan Perusahaan Asuransi JiwaPatungan. Call For Paper Forum Manajemen Indonesia (FMI) Ke-5. Pontianak, Indonesia. Oktober 23-26.

Viverita, Wulandari, S., and Cabanda, E. (2016). Determinants of Cost Efficiency and Productivity Growth of the Indonesian Insurance Industry. International Journal of Knowledge-Based Organizations (IJKBO), 6, 70-82.

Yahoo Finance. (n.d.). Indeks Harga Saham Gabungan (IHSG). Retrieved from https:// finance.yahoo.com/quote/\%5EJKSE? $p=\% 5 E J K S E$ 